\title{
Translation of Selected Igbo Proverbs and Idiomatic Expressions: Implications for Curbing Economic Recession
}

\author{
Joseph Igono, Ugochukwu Ogbonnaya Ogudu \\ Department of French, Umar Suleiman College of Education, Gashu'a, Nigeria
}

Email address:

joesmary2003@yahoo.fr (J. Igono)

\section{To cite this article:}

Joseph Igono, Ugochukwu Ogbonnaya Ogudu. Translation of Selected Igbo Proverbs and Idiomatic Expressions: Implications for Curbing Economic Recession. International Journal of Applied Linguistics and Translation. Vol. 4, No. 1, 2018, pp. 1-8.

doi: $10.11648 /$ j.ijalt.20180401.11

Received: January 13, 2018; Accepted: February 16, 2018; Published: March 19, 2018

\begin{abstract}
This descriptive research analyzes selected Igbo proverbs and idiomatic expressions using translation approach. While literal translation is used to reveal the syntactic structures of the selected fixed expressions in Igbo, semantic translation is also used to reveal the rich meaning of the expressions. The application of these procedures helps reveals the tenets of advice, motivations and blame that are inherent in Igbo proverbs and idioms. It is such values as these that are of reformatory benefits during the periods of social or economic crisis. A number of Igbo proverbs and idioms were collected from Igbo native speakers and some written texts. From this corpus, proverbs and idiomatic expressions that appear to have relevance to nature, social and economic issues were selected and classified into two lists - proverbs list and idiomatic expressions list. These two lists were given to elderly Igbo native speakers who are also linguistically knowledgeable in the language to determine their appropriateness for inclusion in the lists. After this, both literal and semantic translation of the proverbs and idiomatic expressions were made from Igbo into English. Implications are drawn based on what the two translation approaches revealed. At the end of the study, it was found that Igbo proverbs and idioms consist of many wise conceptual frames and reformative tenets capable of motivating the individual and encouraging hard work. The research recommends therefore, that the deployment of rich linguistic resources like fixed expressions have great positive implications in curbing economic crisis since they can be used to give pieces of social advice that will help economic growth of the individuals and the society at large at the moment of crisis.
\end{abstract}

Keywords: Proverbs, Idioms, Translation, Igbo, Economic Recession

\section{Introduction}

Proverbs are fixed expressions that are not uncommon in human language. Thalji explains that proverbs have "meanings that can cover all aspects of life and, this in turn, makes them important elements in peoples' speech" [1]. They are so wide in scope that they could cover such themes as women, professions and occupations, money, love, marriage, divorce, friendship, education and learning, alcohol and drugs, children and parents, taxes, God and religion, telephones, cars and computers [2]. Because proverbs have unique constructions, their shapes are crucial for grasping their semantics. Since they are expressions in a fixed form, they are rarely made up of one word. Instead, they have specific forms that distinguish them from any segment of the language [3].

Idioms, on the other hand, are defined as "a fixed group of words with a special different meaning from the denotation of ordinary sentential constructions" [4]. Adelnia and Hossein, by looking at idioms from their thematic coverage, state that they are "linguistic expressions or lexical items representing objects, concepts or phenomena of material life particular to a given culture" [5]. It is the idiomatic expressions present in any given language that give the language its cultural coloration and timbre. In terms of structure, idioms are similar to proverbs. It is not bizarre then when Larson defines them as "a string of words whose meaning is different from the meaning conveyed by the 
individual words" [6]. But as Larson explains, idiom differs from proverbs in that it "carries certain emotive connotations not expressed in the other lexical items". Because proverbs and idioms can represent any object, concepts or phenomena and they can carry emotive and reflective connotations, their appropriate usage are considered to be vital in difficult moments such as during the period of recession.

The sense of recession in this study does not deviate from the general understanding attributed to the concept. Recession is defined by Amadeo as a period when the economy declines significantly for at least six months. At this point there is often a drop in the following five economic indicators: real GDP, income, employment, manufacturing and retail sales [7]. People often say a recession is when the GDP growth rate is negative for two consecutive quarters or more. But a recession can quietly begin before the quarter. In a layman's understanding, recession is that period when there is increment in poverty and hunger and one finds it difficult to make both ends meet. To pull out of such situation, one requires desperate action through good policy and hard works.

One suggested way of curbing recession is through the promotion of human spirit to work harder through the use of a right language; the use of convincing act of speech rich in fixed expressions. This is the case because fixed expressions are characteristically emotive and pensive. Proverbs and idioms have long been used as a way of providing not only aesthetic coloration to speech but to convince others about certain arguments. Therefore, a collection of rich and relevant proverbs and idioms from diverse background and cultures are veritable source of wisdom and can serve as tool for curbing crisis. Having a pool of fixed expressions from diverse cultural settings can be possible through the medium of translation.

Translation has served as an effective contrastive tool that can be used to evaluate the richness of a language. In this sense, translation becomes not only as a medium of transferring messages from one language into another but also a way of transferring the richness of one cultural norms, wisdom and way of conceptualizing from one language to another.

\subsection{Statement of Problem}

Despite the richness of proverbial sayings and idiomatic expressions, they are rarely studied in their own right from the point of view of moralizing or as instrument of socialization. Most of the studies of proverbs and idioms are often anchored on either contextual literary analysis, stylistics or language studies. For instance, there are no paucity of studies on proverbs and idiomatic expressions used in prose, poetry and drama. In the same vein, there are couples of studies that attempt unraveling figurative structures and semantic nuances that are present in fixed expressions. There are also studies that analyze the nature and types of proverbs that are found in specific languages. What is in dearth however, are studies on the practical functions of proverbs and idiomatic expressions in critical every day needs. This study is an attempt to fill this gap. In this respect, it is considered worthwhile to translate some selected fixed expressions in Igbo culture to see whether they have implications in curbing economic recession.

\subsection{Objectives of This Research}

The objectives of the study include:

i. Providing literal and correct translations of selected Igbo proverbs and idioms to reveal their linguistic structures and their correct meaning.

ii. Ascertain the positive implications of the translation of the selected Igbo proverbs and Idiomatic expressions on economic recession.

\subsection{Significance of This Study}

This study is a paradigm shift based on the assumption that the collection and translation of idioms and proverbs will be useful resource materials for relearning what people thought, believed and valued. Such thoughts, believes and values can be of moral and socializing benefits to both individuals and groups.

\section{Literature Review}

Scholars notably Ngwugbe and Matthew generally agree that recession is an economic contraction experienced in business cycle. This contraction often leads to a slowdown in economic activities within a country [8]. A nation is considered to be in recession if there is a halt in business growth for two consecutive quarters. Igberaharha enumerates certain macro and micro level indices that are considered to be vital determinants in measuring the level of recession. Some of these major and micro indices include growth, unemployment, livelihood, decreased demand and consumption, price instability and rising cost and household level impacts [9]. Inferring from these indices, it could be said that the critical challenges during recession will be how to boost economic growth, promote employment, improve the welfare of citizens, increase consumption and demands as well as improve household level impacts. Coping with these challenges will require the contributions of what Igono identifies as the three active agents in economic recession namely, the government; the investors (National or International) that produce and employ workers; as well as the consumers (the citizen) [10].

Economic events, whether positive or negative, are integral properties of people's culture. The same can be said about challenges, mutual solutions, and communication. Specifically, effective communication is identified by Igono as a vital tool for enriching national solutions and eliminating challenges linked to economic issues [11]. Since language is the instrument through which communication is made possible and fixed expressions are parts of languages, they are exploited to motivate and arouse a sense of commitments among the people. Good enough Samovar et al. explain that in almost all culture, proverbs provide vital set of values and beliefs for members of such culture and reflect the wisdom, 
biases, and even superstitions of a culture [12]. This same assertion also applies to idiomatic expressions.

By nature, proverbs and idiomatic expressions are vivid, colorful, concise, emotive and thought-provoking linguistic constructions. They are considered by folks as the right language with the ability to awaken the human spirit and promote quality service delivery. This is because proverbs and idioms are unique in terms of their particular rhetoric and aesthetic appeal, not only to the speakers but also to the listeners. In addition, proverbs and idioms are compendium of wits that have endured over time. This explains why Nwoga sees them as 'the wisdom of many and the wits of one; the expression and wisdom of several ages gathered and summed up in one expression and as the edged tools of speech" [13]. This assertion reaffirms the general belief that fixed expressions are sayings or thoughts that constitute the reservoir of the religious, historical, socio-cultural and scientific knowledge of the people. It is a compact of wisdom, and a vehicle of transmitting traditional knowledge.

On a functional level, Honeck holds that proverbs (and idioms as well) have certain properties that make them crucial for every day purposes [14]. This view is also shared by Dabaghi et al. who believe that like idioms, proverbs possess 'the power and wisdom of many people behind them' and thus making them effective for pragmatic functions [15]. Meider states succinctly that "proverbs are a significant rhetorical force in various modes of communication, from friendly chats, powerful speeches, and religious sermons to lyrical poetry, best-seller novels, and influential mass media" [16]. Yet, available proverbs and idiomatic expression in each language in the world is quite unique though some appear to have universal appeal. Outside that, expressing an idea which was credited to Roy by Samovar et al, Dabaghi states as fact that "examination of these ... transmitted values offers an excellent means of learning about another culture" [17].

One way of accessing the richness of fixed expressions is through the medium of translation. These can be done using a number of translation strategies. For example, literal translation can be used to understand the linguistic structure of fixed expressions. By literal translation, it is meant a strategy that relies on the source language structure from which the translator transfers all the words into the target language taking less account of the contextual and cultural aspects of the translation unit. Another strategy that can be used is semantic translation. Semantic translation is described by Newmark as that translation procedure that takes more account of the aesthetic value (that is, the beautiful and natural sounds of the SL text, compromising on 'meaning' where appropriate so that no assonance, word-play or repetition jars in the finished version. Further, it may translate less important cultural words by culturally neutral third or functional terms but not by cultural equivalents and it may make other small concessions to the readership [18].

The choice of semantic translation procedure over a procedure that may be termed faithful is because semantic translation is less dogmatic yet uncompromising. Semantic translation can be used to render correct translation of fixed expressions when literal translation does not offer adequate meaning. This study will attempt to translate some selected Igbo proverbs and Idioms in order to see their ability to awaken the human spirit and promote the sense of hard work for the purpose of curbing economic recession.

\section{Methodology}

A number of Igbo proverbs and idioms were collected from Igbo native speakers and some written texts. From this corpus, proverbs and idiomatic expressions that appear to have relevance to nature, social and economic issues were selected and classified into two lists - proverbs list and idiomatic expressions list. After this, a literal and semantic translation of each proverbs and idioms were tabulated in the lists. In this work, semantic translation is tagged interpretation. Twenty seven (27) proverbs and eighteen (18) idiomatic expressions were selected for the purpose of these analyses.

These two lists were given to elderly Igbo native speakers who are also linguistically knowledgeable in Igbo language to determine the appropriateness of the proverbs and idioms for inclusion in the lists. After this, both literal and semantic translation of the proverbs and idiomatic expressions were made from Igbo to English.

Positive implications are drawn from the translation of the selected proverbs and idioms. The Igbo proverbs were categorized into proverbial expressions that contain the following elements: woman, children, object, justice, society, religion, and question. Below is the presentation of the translations.

\subsection{Analysis of the Translations of the Selected Proverbs}

It must be stated from the on-set that the environment in which literal translation can be correctly applied is restricted. A wrong application of literal translation in certain cases can lead to strange and meaningless translation. The purpose of its use is that it serves as good tool for linguistic comparison between languages. Tables are presented in this section showing the selected Igbo proverbs (second column), their literal translations (third column) and the correct translation (fourth column). A brief comment comes after each table to make drawing the implications easier.

Table 1. Proverbs on Nature.

\begin{tabular}{|c|c|c|c|}
\hline S/No. & Igbo Proverbs & Literal Translation & Correct Translation \\
\hline 1 & Mmiri anaghi agbaru nisi ya. & Water does not come out of its source polluted. & One does not spoil what one is expected to do. \\
\hline 2 & $\begin{array}{l}\text { Osimiri adighi eri onye ọna ahughi } \\
\text { ukwu ya anya. }\end{array}$ & The River only drown him/her that it sees its legs & $\begin{array}{l}\text { when one is where } s / \text { he is not supposed to be, } s / \text { he } \\
\text { should take what } s / \text { he sees }\end{array}$ \\
\hline
\end{tabular}




\begin{tabular}{llll}
\hline S/No. & Igbo Proverbs & Literal Translation & Correct Translation \\
\hline 4 & Anaghi ekpuchi anwụrụ ọkụ. & One does not cover smoke. & Nothing is hiding under the sun. \\
5 & Awọ anaghị agba ọsọ ehihe na efu. & A toad does not run in the afternoon for no reason. & Nothing happens without a cause. \\
\hline
\end{tabular}

The proverbs in the table above moralize through on the symbols of water, river, time, smoke and a toad (a water loving animal). A close study of the correct translation of the proverbs in table 1 above indicates that the first two proverbs teach about commitment and discourage being a busybody. This is done through the symbol of water and the river. The third encourages sharing and discourages wickedness through the symbol of time, the fourth promotes the spirit of exploit through the symbol of smoke and the last in the table implies that human experiences are the product of their actions. If one wants to be rich, s/he needs to work. Here, an animal symbol in the form of a toad is used.

Table 2. Proverbs on man.

\begin{tabular}{|c|c|c|c|}
\hline S/No. & Igbo Proverbs & Literal Translation & Correct Translation \\
\hline 1 & $\begin{array}{l}\text { Onye ụbiam adighi aza } \\
\text { omeọkachi. }\end{array}$ & $\begin{array}{l}\text { An indigent does not take the title of omeokachie (one } \\
\text { who complete whatever he put his hand into). }\end{array}$ & Heroism is not for the indolence. \\
\hline 2 & $\begin{array}{l}\text { Onye mmiri amaghi amagi } \\
\text { mmiri nwere okpukpu }\end{array}$ & $\begin{array}{l}\text { He who is not bitten by water does not know that } \\
\text { water has bone. }\end{array}$ & Life is full of surprises for those who live it. \\
\hline 3 & $\begin{array}{l}\text { Onye anwụ gbara na atụ ogboro } \\
\text { ijiji egwụ. }\end{array}$ & One who is sting by a bee is afraid of greenfly. & Once bitten, twice shy. \\
\hline 4 & Onye hụ ihe ka ubi oré ọba. & $\begin{array}{l}\text { When one experiences a problem that is greater than } \\
\text { the value of his farm, he sells the yam barn. }\end{array}$ & $\begin{array}{l}\text { Hidden wealth cannot be preserved on turbulent } \\
\text { days. }\end{array}$ \\
\hline 5 & Atọ dike n'ala, anụ uzu ya. & $\begin{array}{l}\text { Fall a valiant man on the ground and the sound will } \\
\text { be tremendous. }\end{array}$ & $\begin{array}{l}\text { The downfall of a famous man attracts public } \\
\text { attention. }\end{array}$ \\
\hline 6 & $\begin{array}{l}\text { ọnwere onye etinyere azụ na } \\
\text { ọnụ, ya si na ya achọ ghi. }\end{array}$ & There is no one who does not like soup with fish in it. & everyone desires good things \\
\hline 7 & $\begin{array}{l}\text { Onye njem ka onye isi awu ima } \\
\text { ighe. }\end{array}$ & $\begin{array}{l}\text { One who travels wide exceeds a gray-haired person in } \\
\text { knowledge. }\end{array}$ & $\begin{array}{l}\text { One who travels wide is more exposed to the things } \\
\text { of modern life than the one who stays at home. }\end{array}$ \\
\hline 8 & Osọndu anaghị agwụ ike. & Running for one's life does not exhaust one. & Greatness can be attained even with fear. \\
\hline 9 & Onye ka madụ ka chị ya. & He who is greater than one is greater than his gods. & One who is richer than another is greater than him. \\
\hline
\end{tabular}

In table 2 above, human symbol is used to teach a number of virtues and provide advice. For example, the proverbs in both columns I and 2 discourage indolence and encourage the virtue of hard work. The one in column 3 speaks of perseverance while the one in column 4 gives advice on when to make investment and when to make saving. In column 5 , it is how to avoid reproach, in column 6 , the fact that struggling is not a sin, column 7 that even the weak can be an achiever and the last one teaches that greatness ensures independence and control. Looking these meaning, it shows that these proverbs have positive implications for mentoring anyone in crisis.

Table 3. Proverbs on child.

\begin{tabular}{|c|c|c|c|}
\hline S/No. & Igbo Proverbs & Literal Translation & Correct Translation \\
\hline 1 & Nwata kwọ aka osoro okenye rié nri. & $\begin{array}{l}\text { If a child washes his hands clean, he dines with the } \\
\text { elder. }\end{array}$ & $\begin{array}{l}\text { The young who attains greatness dines } \\
\text { with the elders. }\end{array}$ \\
\hline 2 & $\begin{array}{l}\text { Nwata etoghi eto wara ọgọdọ ikukuku we } \\
\text { ọburuya ma ọgọdọ ya. }\end{array}$ & $\begin{array}{l}\text { When an underage person tie wrapper, the wind will } \\
\text { exposed his nakedness. }\end{array}$ & $\begin{array}{l}\text { One does not embark on task harder than } \\
\text { oneself. }\end{array}$ \\
\hline 3 & Okolo anghi akari onye kuru ya aka. & $\begin{array}{l}\text { A young man cannot be stronger than the one that } \\
\text { supports him. }\end{array}$ & $\begin{array}{l}\text { A child cannot be above the authority of } \\
\text { his parent. }\end{array}$ \\
\hline
\end{tabular}

In table 3, the use of the child of a child is very instructive. It is meant to teach the young good morals. From the early age, children are taught this proverb to inform them that success is not negotiable. Of course, it is known that Igbo society is classed society where recognition is based on personal achievement. Hence, the young know that they have to work hard and take titles that enable them to mingle with the elders. They are also taught that life is full of ups and downs so they ought not to live their life carelessly. They are also admonished to be shrewd since the main occupation of the Igbos which is business requires that.

Table 4. Proverbs on woman

\begin{tabular}{llll}
\hline S/No. & Igbo Proverbs & Literal Translation & Correct Translation \\
\hline 1 & Ogori nuo di n'abọ o mara nke ka mma. & $\begin{array}{l}\text { A woman who marries two husbands knows the one } \\
\text { that loves her best. }\end{array}$ & Different works, different benefits. \\
2 & Onụ ọma ka nwanyi ji anara di ya ihe. & $\begin{array}{l}\text { A sweet tongued woman does not suffer denial from } \\
\text { her partner. }\end{array}$ & $\begin{array}{l}\text { A polite response wards away further } \\
\text { trouble. }\end{array}$ \\
& $\begin{array}{l}\text { Nwayi muta ité ofé mmiri mmiri, di ya } \\
\text { amụta ịpị ụtara aka were suru ofé }\end{array}$ & $\begin{array}{l}\text { If a woman decides to make soup watery, the husband } \\
\text { will learn to dent foo-foo before dipping it into soup. }\end{array}$ & Different tactics for different situation. \\
\hline
\end{tabular}

In table 4 above, the symbol of a woman is used to admonish people to be flexible in the choice of whatever they want to do. 
They are also admonished to be diplomatic in speech and shrewd in their dealing with people.

Table 5. Proverbs on object.

\begin{tabular}{llll}
\hline S/No. & Igbo Proverbs & Literal Translation & Correct Translation \\
\hline 1 & E ne nie nwaité oggbanoụ ọku. & $\begin{array}{l}\text { When you overlook small cooking pot, it will put off the } \\
\text { fire. }\end{array}$ & $\begin{array}{l}\text { A rejected stone has become the } \\
\text { corner stone. }\end{array}$ \\
2 & $\begin{array}{l}\text { Kama mmanya ga esetara enyi na abọ okwu ka } \\
\text { ite mmanya a hu, kọwa na ụzọ. }\end{array}$ & $\begin{array}{l}\text { if wine is going to cause quarrel between friends let the } \\
\text { wine pot break along the way. }\end{array}$ & $\begin{array}{l}\text { He is accursed who ignites } \\
\text { enmity between friends. }\end{array}$ \\
\hline
\end{tabular}

These two proverbs using the symbol of stone and an unknown personality talk about generosity and peace. While the first proverb encourages the Igbo to remember that no situation is permanent and no one holds the destiny of the other in his hand, the second admonishes them to be always peaceful since a trouble maker is loathed in any community.

Table 6. Proverbs with question tag.

\begin{tabular}{|c|c|c|c|}
\hline S/No. & Igbo Proverbs & Literal Translation & Correct Translation \\
\hline 1 & $\begin{array}{l}\text { Oke soro nwere ngbaa mmiri, ahu kọ } \\
\text { nwere ọga akọwa oke? }\end{array}$ & $\begin{array}{l}\text { Foolish rats join lizard in the rain; if the body of the } \\
\text { lizard get dried, will that of rats get dried too? }\end{array}$ & $\begin{array}{l}\text { Can the success of one translates into that of } \\
\text { another? }\end{array}$ \\
\hline 2 & A na eji ọtụtụ ama njọ ahia? & $\begin{array}{l}\text { Can bad market be predicted from the look of the } \\
\text { morning hours? }\end{array}$ & $\begin{array}{l}\text { Can the early days of a child predict the state of } \\
\text { wealth or wisdom in its adult life? }\end{array}$ \\
\hline 3 & Onye nyere nwa osa akwu ahuru ahu? & Who gives squirrel roasted palm fruit? & Who give a poor man good thing of life? \\
\hline
\end{tabular}

The first proverb in table 6 forbids people making investments out of share jealousy. It reminds people also that each person has its destiny using the allegory of the rats and the lizard, two species of animals with different skin properties for absorbing rain water. The second proverb has dual interpretations. It reminds the people of the need not to be discouraged by one's past failures or to boast unnecessary since one is ignorant of one's future. The one teaches the folk to abhor poverty and struggle for wealth. it is also used when one is in need of favor from friends or siblings.

Table 7. Proverbs on justice.

\begin{tabular}{llll}
\hline S/No. & Igbo Proverbs & Literal Translation & Correct Translation \\
\hline 1 & $\begin{array}{l}\text { Egbe bere, ugo bere nke siri } \\
\text { Ibe ya ebena nkụ kwaya. }\end{array}$ & $\begin{array}{l}\text { Let the hawk perch, let the eagle perch, the } \\
\text { one that forbids the other, let its wing break. } \\
\text { it is the head that disturb that the wasp will } \\
\text { sting. }\end{array}$ & $\begin{array}{l}\text { Let the poor live and let the rich live, the one who tells the other } \\
\text { not to live, let him be the first to die. }\end{array}$ \\
$\begin{array}{lll}\text { Isi kotera ebu ka ọ n'agba. } \\
\text { Okenye were ihe nwata elu, } \\
\text { aka gbou ya mgbu, owetuo } \\
\text { ya ala. }\end{array}$ & $\begin{array}{l}\text { When an elder decided to take up what } \\
\text { belong to a child, he will bring it down when } \\
\text { his hand is tired. }\end{array}$ & $\begin{array}{l}\text { When an elder decided to take what does not belongs to him, } \\
\text { ikpe. }\end{array}$ \\
4
\end{tabular}

The first proverb in this table is very popular since it admonishes people of the need to be accommodating and have good disposition for sharing. It also encourages the Igbo community not to accept those who refused to cohabite with their fellow Igbos simply because they felt they will be inconvenienced. The second proverb calls for self-control in everything one does. The third proverb reminds the people that nature knows how to balance itself. The last proverb in the table alerts the people that there are consequences that follow every human action thus warning the people to be mindful of what they do.

Table 8. Proverbs on society.

\begin{tabular}{llll}
\hline S/No. & Igbo Proverbs & Literal Translation & Correct Translation \\
\hline 1 & $\begin{array}{l}\text { Mberedé njiri dike ma ọ bu } \\
\text { mberedé ka eji ama dike. }\end{array}$ & $\begin{array}{l}\text { A sudden event may be too much for a strong man but that } \\
\text { is what determined the strength. }\end{array}$ & The heroism of a hero is determined by \\
impossibility. \\
2 & $\begin{array}{l}\text { Ihe okenye nọ ala hu nwata } \\
\text { anaghi ahu ya na enu osisi. }\end{array}$ & $\begin{array}{l}\text { Anything an elderly person sits down and see a child } \\
\text { cannot see it even if he climbs a tree. }\end{array}$ & The wisdom of an old man is immense. \\
& A hara dike izu agbahara ya ọzo. & $\begin{array}{l}\text { If something is discussed in absence of an influential } \\
\text { person it will be discussed for a second time. }\end{array}$ & $\begin{array}{l}\text { Decision taken in the absence of an influential } \\
\text { town leader is a waste of time. }\end{array}$ \\
\hline
\end{tabular}

The three proverbs translated in this table all have to do with leadership. The first one reveals that the true character of a leader is reveal in the face of difficulty. The second teaches that in the days of trouble, experience is crucial and those who have it must be consulted. The third teaches that skillful and influential people need not be neglected when critical issues are discussed.

\subsection{Analyses of Selected Idiomatic Expressions}

The category of Igbo idiomatic expressions selected for analysis are those whose syntactic patterns are negative but whose semantic implication is of positive value. These idiomatic expressions also include those describing as bad what is naturally good. These idioms communicate their 
meaning by using a bad attribute to describe or express what is actually good. The idioms that fall into this category are:

Describing excellent Performance or achievement in terms of destruction action

This type of expression is used in describing a person or someone who performed very well in what $\mathrm{s} /$ he does in term of destruction. The idioms that fall into this category include:

1. O siri ajọ ike.

Literal translation: s/he is badly strong

Correct meaning: $\mathrm{s} / \mathrm{he}$ is very strong

2. Nwanyi a bu oke ozu.

Literal translation: this woman is a huge corpse.

Idiomatic meaning: this woman is a very important person.

3. Nwoke a egbue ọchu.

Literal meaning: this man has committed murder.

Correct meaning: this man has done wonderfully well.

4. A kọo onye ujo onu ogbue ọchu.

Lilteral meaning: if a coward is rebuked he commits murder.

Correct meaning: if a coward is rebuked he excels in bravery

5. O talu amosa.

Literal meaning: the person chewed witchcraft.

Correct meaning: the person is excellent in his work.

6. O de jiri pen.

Literal meaning: he broke his pen while writing.

Correct meaning: he wrote excellent

Describing a virtue or achievement in term of physical or moral defect

1. O naghi anu ihe (o bu ghi nti)

Literal meaning: he has no ear

Correct meaning: he is indefatigable/ dauntless.

2. O bụ oke ozu.

Literal meaning: he is a huge corpse

Correct meaning: he is a very important person.

3. O bụ ọkponkụ.

Literal meaning: he is dried up (like a piece of wood)

Correct meaning: he is a hero

4. $\mathrm{O}$ bu ékwé ékwè.

Literal meaning: he never believes (in anything).

correct meaning: He is preserving (he never gives up).

Describing a happy situation in term of a sad incident

1. Akwa gbara oku n'ahia tata.

Literal meaning: cloth was burnt in the market today.

Correct meaning: cloth sold very well in the market today.

2. Ji nyuru nsi n'ahia.

Literal meaning: yam deposited face in the market.

Correct meaning: yam was cheap in the market

3. Akwụkwọ riri ya isi.

Literal meaning: book full his head.

Correct meaning: he loves reading very much.

Describing a man of excellence in terms of a wicked or evil spirit or animal
1. O bu ajo mmuọ.

Literal meaning: he is wicked spirit.

Correct meaning: he is a performer of a difficult task.

2. O bu agu.

Literal meaning: he is a leopard

Correct meaning: he is a great man.

3. O bụ ajọ nnunu.

Literal meaning: he is an evil bird.

Correct meaning: he is extremely sagacious.

\section{Discussion}

The first objective of the study is to provide literal and correct translations of selected Igbo proverbs and idioms to reveal their linguistic structures and correct meaning. What literal translation shows in this work is that in many cases, following such a translation procedure may not reveal the rich moral and experiential lessons of some Igbo fixed expressions. Take for instance the translation of "O bụ ajọ nnunu". In a literal sense, this expression will translate as 'he is an evil bird' but the actual meaning of the expression is that one is extremely sagacious. Another example is " $\mathrm{O}$ bu ajo mmuọ" which literal means 'he is wicked spirit' but the correct interpretation is that one is a good executor of a difficult task. Some other examples are:

i. Akwa gbara oku n'ahia tata.

Literal meaning: cloth was burnt in the market today.

Correct meaning: cloth sold very well in the market today

ii. O siri ajọ ike.

Literal translation: s/he is badly strong

Correct meaning: $\mathrm{s} /$ he is very strong

iii. Nwanyi a bu oke ozu.

Literal translation: this woman is a huge corpse.

Correct meaning: this woman is a very important person.

By offering correct translations of selected Igbo proverbs and idioms using semantic translation strategy, one is able to reveal the real meaning of the proverbs and idioms. These correct translations enable the consumers of the text to decipher the correct meaning of the translation units. For instance, "Akwụkwọ riri ya isi" will translate literally as 'one's head is filled with books' the semantic interpretation is that one loves reading very much. Another example is the translation of the expression "Akwa gbara oku n'ahia tata" which will literally translate as "cloth was burnt in the market today' but the semantic translation is cloth sold very well in the market today.

The second objective of the study is to ascertain the positive implications of the selected Igbo proverbs and Idiomatic expressions on economic recession. As could be deduced from the lists of fixed expressions translated, they are rich in moral and motivational cues that can be used to promote hard work rather than indolence, generosity rather than stinginess, accommodation rather than hostility, sincerity rather than dishonesty, shrewdness rather than foolishness, humility and consultation rather than arrogance and self-will, cherishing wealth gotten through hard work 
rather than poverty.

All these have positive implication for curbing economic recession. When people work hard for example, they can overcome any economic crisis that befalls them. The use of proverbs and idioms in daily conversations and discussions is a familiar linguistic convention among the Ibos and indeed among other tribes and races in Africa. In Things fall Apart, Achebe affirms that "proverbs are the oil with which words are eaten". Igbo language therefore, has various ways of expressing thoughts through effective use of proverbs and idioms.

Since fixed expressions in any language are condensation of varieties of cultural form and norms found even in ordinary discourses such as narrations, patterns of speech of social organization, religious beliefs and ritual, they are important medium for behavioral modification and encouragement. This explicates to some extent why it is quite not uncommon to see proverbs employ in situations like bride price rituals, settlements of disputes, family meeting, to give piece of advice, to praise or blame a person on issues or for encouragement. It is these attributes that make the selected fixed expressions in Igbo apt for curbing economic recessions.

\section{Conclusion and Recommendations}

In this study, lists of selected Igbo proverbs and idioms were compiled based on their moral and social relevance. These lists were translated literally and semantically. While the literal translation reveals the syntactic nature of the fixed expressions under study, their semantic translations make their moral implications self-evident. Being part of the traditions and wisdom of the Ibo people, proverbs and idioms have the ability to motivate people to change for the better be it man, woman, young or old. It also has the ability to encourage the lazy person to become a hardworking person since hard work is welcomed and praised in the Ibo society. This implies that when a lazy person changes to a hardworker and a bad man or a woman or a criminal change to a better man or woman, then it will help in economics growth. Based on this, it is recommended that:

1. More Igbo proverbs and idioms should be translated to expose their moral and aesthetic imports.

2. People should be made conscious of the inherent values of proverbs and idioms and be encouraged to assimilate them for use during hard times.

3. People should learn how to use proverbs and idioms to offer praises and encouragement to people when they are having economic challenges.

\section{Appendix}

\section{Appendix I. List of Selected Igbo Proverbs}

1. Onye ga-asi na ofe nne a adịghi ụtọ

2. Onwere onye etinyere azu na ọnu, ya sị na ya achọ ghị

3. Onye nyere nwa osa akwu ahuru ahu

4. Ewu mmadu abuo new na ehị n'ilo

5. Onye mmiri amaghi, amaghi na miri nwere okpukpu
6. Onwe ughi ihe anya huru gba obara

7. Onye anwu gbara na atu ogoro ijiiji egwu

8. Onye njen ka onye isi amaighi

9. Oso ndu anaghi agwu ike

10. Ogori nuọ di n'abọ o mara nke ka mma

11. Oke soro nwere mgba mmiri ahu kun nwere oga akowa oke

12. Onye hụ ihe ka ubi ore ọba

13. Jiri ehihe chọ ewu ojie

14. Awọ anaghi agba ọsọ ehihe na efu

15. Echi di ime onye ma ihe ogga amụ

16. Anaghi eji ụtụtụ ama njọ ahia

17. Onye tara aki tufoo okwite ( $\mathrm{m}$ boina) oche na ụnwụ agaghi abịa ọzọ

18. Otu aka ruta mmanu ozuru aka nile

19. Onu oma ka nwanyi ji anara di ya ihe

20. Mberede nyiri dike ma ọbu mberede ka eji ama dike

21. Ogologo abughi na nwam etola

22. Wepu aka enwe na-ofe oge ọ dibeghi ka nke madụ

23. Nwata etoghi eto chu ihe gburu nnaya egbu ya

24. Nwata etoghi eto wara ogodo ikuku o buru ya na ogodo ya

25. Nwata kwọ aka o soro okenye rie nri

26. ozụ shiwe ishi enyi ka nwa nne a laa

27. A hara dike izu agbaharia ya

\section{Appendix II. List of Igbo Idioms}

1. Ihe oma mere ibe $\mathrm{m}$, mekwara $\mathrm{m}$

2. Onye ndidi na-ata azu ukpoo

3. Oke osisi

4. Ome mma mere onwe ya

5. Ike nna ya

6. Mma ihu n'abọ

7. Ugo charaa cha adịghe échu écuu

8. Onye ubiam adighi aza omeokachie

9. Onwa na etiriola

10.bu ekweé ékwè

11. Akwa gbara ọkụ n'ahịa taata

12.ọ bu oke ozu

13.ọ mara ajo mma

14. Mere ya ma mgbawaisi

15. Agu nnaya

16. Ajọ nnumu

17. Iberibe bụ orịa

18. Oke mmuo

\section{References}

[1] Thalji, M. Basam. (2015). The Translation of Proverbs: Obstacles and Strategies. Amman, Jordan: Unpublished Thesis. Middle East University.

[2] Litovikina, A. (2014). Anti-Proverbs. In H. Gotthardt \& M. Varga, (Eds.). Introduction to Paremiology: A Comprehensive Guide to Proverbs Studies. Pp. 326 -347.

[3] Barajs, E. (2010). The Functions of Proverbs in Discourse. Germany: Deustche National bibliothek. 
[4] Longman Dictionary of English Idioms. (1998). UK: Longman Group Ltd.

[5] Adelnia, A. \& Hossein Vahid Dastjerdi (2011). "Translation of Idioms: A Hard Task for the Translator". Theory and Practice in Language Studies. Vol. 1, No. 7, pp. 879-883.

[6] Larson, M. (1984). Meaning Based Translation: A Guide to Cross Language Equivalence. London \& New York: University Press of America.

[7] Amadeo K. (2017). What Is a Recession? Examples, Impact, Benefits.

[8] https://www.thebalance.com/what-is-a-recession-3306019.

[9] Ngwube, A, \& Matthew Ogbuagu (2014). "Global Financial Crisis and Nigeria Economy." Global Journal of Management and Business Research (B). Vol. XIV, issue IV, version 1.

[10] Igberaharha, C. O. (2017). "Challenges of Economic Recession among Developing Countries: Africa Perspective. International Journal of Innovative Research in Education, Technology \& Social Strategies. Vol. 4. No. 1, pp. 23-30.

[11] Igono, M. N. (2017) "Effective Communication and Quality Management Strategies as a way of Curbing Challenges of Economic Recession in Nigeria" a paper presented at the $9^{\text {th }}$ National Conference of the Colleges of Education Academic Staff Union, North-East Zone on Tuesday $5^{\text {th }}$ December, 2017 at Umar Suleiman College of Education, Gashua, Nigeria.
[12] Igono,M.N.(2017) "Effective Communication and Quality Management Strategies as a way of Curbing Challenges of Economic Recessionin Nigeria"

[13] Samovar, Larry A., Richard E. Porter, and Lisa A. Stefani. (2009). "Communication between Cultures". Edited by Randall Adams. Wadsworth Series in Communication Studies, 3rd ed,. Belmont, CA: Wadsworth Publishing.

[14] Nwoga D. I (1972). Appraisal of Igbo proverbs and Idioms. Nsukka: University of Nsukka.

[15] Honeck, R. (1997). A proverb in mind: the cognitive science of proverbial wit and wisdom. USA: Lawrence Erlbaum.

[16] Dabaghi, A., Pishbin, E \& Niknasab, L. (2010). "Proverbs from the Viewpoint of Translation". Journal of Language Teaching and Research, Vol. 1, No. 6, pp. 807-814, November 2010. DOI:10.4304/j1tr.1.6.807-814.

[17] Mieder, W. (2004). Proverbs: A Handbook. London: Greenwood Press.

[18] Dabaghi, A. Pishbin, E\&Niknasab, L. (2010). "Proverbs from the View point of Translation"

[19] Newmark, P. (1988). A Textbook of Translation. New York: Prentice Hall. 